\title{
Gambaran Pengembangan Ide Bunuh Diri Menuju Upaya Bunuh Diri
}

\author{
Ni Wayan Putri Cempaka Karisma F ${ }^{\mathbf{1}}$, I Gusti Ayu Diah Fridari² \\ ${ }^{1,2}$ Program Studi Psikologi, Fakultas Kedokteran, Universitas Udayana, Jalan PB Sudirman \\ cempakaputri.pc@gmail.com
}

\begin{abstract}
Abstrak
Bunuh diri menjadi salah satu penyebab kematian terbanyak di dunia. Penelitian terdahulu menyebutkan bahwa sebagian besar individu yang memiliki ide bunuh diri tidak melakukan upaya bunuh diri, namun lebih banyak individu yang memiliki ide dibandingkan individu yang melakukan tindakan bunuh diri. Namun secara logis, tindakan bunuh diri diawali oleh ide bunuh diri. Peneliti melakukan telaah literatur terkait pengembangan ide bunuh diri menuju sebuah bentuk upaya bunuh diri pada individu. Ide bunuh diri merupakan pemikiran mengenai perencanaan, perilaku dan hasil tentang bunuh diri, kematian, serta perilaku yang merugikan diri sendiri. Faktor psikologis menjadi faktor dominan penyebab munculnya ide bunuh diri. Hasil dari kajian telaah literatur yang dilakukan menunjukkan bahwa ide bunuh diri berkembang menuju upaya bunuh diri akibat dari berbagai peristiwa dan pengalaman kehidupan individu.
\end{abstract}

Kata kunci: Ide bunuh diri, upaya bunuh diri

\begin{abstract}
Suicide become the most caused of death in the world. The previous research mentioned that most individual whose has the suicidal ideation doesn't put effort on it and more individuals were just have the idea if compare to those individuals that done suicide. Though in a logical way, suicide is start by the idea itself. Therefore, writer (of this research) has been doing literature evaluation related to development of suicide idea become the actual suicide in that individual. The suicida ideation is a thought about planning, doing and result about suicidal, deaths, and also the behave that a self-harmful. Psychology factors become the dominant factors which is caused of the suicida ideation. The results of literature evaluation which has done showed that the suicida ideation become real action of suicide affects from the case and experiences in $f$ individual life itself
\end{abstract}

Keyword: Suicidal ideation, suicide attempts

\section{Pendahuluan}

Secara global bunuh diri menjadi salah satu penyebab kematian terbanyak di dunia. Bunuh diri merupakan kematian akibat perilaku negatif yang diarahkan pada diri sendiri (Klonsky May \& Saffer, 2016). Menurut World Health Organization (2019) hampir 800.000 orang meninggal akibat bunuh diri disetiap tahunnya atau dengan kata lain setiap 40 detik satu orang meninggal akibat bunuh diri. Selain, itu setiap terjadi satu tindakan bunuh diri akan diikuti oleh 20 upaya bunuh diri. Menurut data Badan Pusat Statistik 
diketahui bahwa telah terjadi bunuh diri sebanyak 812 kasus di Indonesia yang dilaporkan pada tahun 2015 (Dewan Pers, 2019).

Bunuh diri disebabkan oleh rasa sakit psikologis yang tak tertahankan yang disebut psychache yang ditunjukkan dengan sakit psikologis dalam jiwa dan pikiran, kesedihan, rasa malu, bersalah, kesepian, penghinaan, kecemasan serta ketakutan (Shneidman dalam Leenaars, 2010). Ketika individu memiliki pengalaman tidak menyenangkan semasa hidupnya, hal tersebut dapat menimbulkan rasa sakit secara psikologis. Kemudian ketika individu sudah tidak mampu menghadapi rasa sakit psikologis tersebut maka akan mendorong terjadinya tindakan bunuh diri.

Setiap tindakan manusia selalu diawali oleh proses kognitif, bunuh diri yang diawali oleh sebuah ide atau pemikiran untuk bunuh diri. Ide bunuh diri merupakan pemikiran mengenai perencanaan, perilaku dan hasil tentang bunuh diri, kematian, serta perilaku yang merugikan diri sendiri (Reynolds, 1991). Menurut Shneidman (dalam Leenaars, 2010) ide bunuh diri merupakan sebuah pemikiran, perencanaan, pertimbangan untuk melakukan bunuh diri. Dalam penelitian yang dilakukan oleh Vilhjalmsson, Kristjansdottir dan Sveinbjarnardottir (1998) diketahui bahwa terdapat beberapa variabel yang secara signifikan berhubungan dengan ide bunuh diri yaitu kesulitan keuangan, dukungan materi yang rendah, kesulitan keluarga, tekanan hukum, persepsi stres, kondisi kronis seperti penggunaan alkohol secara berlebihan, kesulitan (depresi, kecemasan, keputusasaan dan rasa sakit), harga diri yang rendah dan external locus of control.

Berdasarkan pemaparan tersebut diketahui bahwa ide bunuh diri merupakan awal dari upaya serta tindakan bunuh diri, yang mana fenomena bunuh diri menjadi salah satu penyebab kematian terbanyak di dunia. Oleh karena itu kajian lebih lanjut terkait ide bunuh diri memiliki urgensi yang penting dan bermanfaat bagi pengembangan ilmu pengetahuan. Kajian ini bertujuan untuk memberikan informasi kepada masyarakat dalam perencanaan pencegahan bunuh diri di masa mendatang.

\section{Pembahasan}

Ide bunuh diri merupakan pemikiran mengenai perencanaan, perilaku dan hasil tentang bunuh diri, kematian, serta perilaku yang merugikan diri sendiri (Reynolds, 1991). Menurut Liu, Usman, Zhang, Raza, dan Gul (2019) secara umum ide bunuh diri termasuk pikiran dan kognisi mengenai perilaku bunuh diri. Tindakan terkait dengan kematian yang disebabkan oleh bunuh diri diawali dengan adanya sebuah ide, pikiran atau rencana untuk melakukan bunuh diri. Menurut (Nock, Borges, Bromet et al., 2008) sebagian besar individu yang memiliki ide bunuh diri tidak melakukan upaya apapun dan lebih banyak individu yang memiliki ide bunuh diri dibandingkan dengan individu yang melakukan upaya bunuh diri. Meski demikian Ranieri, Steer, Lavrence, Rissmiller, Piper dan Beck (1987) menyatakan bahwa ide bunuh diri secara logis merupakan awal dari upaya bahkan tindakan bunuh diri. 
Ide bunuh diri dapat dipicu oleh berbagai faktor dan faktor psikologis menjadi faktor dominan atas timbulnya ide bunuh diri (Aulia, Yulastri \& Sasmita, 2019). Salah satu faktor psikologis yang mendorong ide bunuh diri adalah depresi (Mackenzie et al., 2011). Selain itu depresi telah diidentifikasi menjadi prediktor ide bunuh diri (Ibrahim et al., 2014). Depresi dapat bersumber dari kognisi negatif, yaitu pandangan negatif yang menyebabkan perasaan depresi, menyebabkan distorsi negative pada penilaian diri, pengalaman hidup, keputusasaan dan pesimisme. (Sulistyorini \& Sabarisma, 2017)

Menurut Vilhjalmsson, Kristjansdottir dan Sveinbjarnardottir (1998) dukungan materi yang rendah, kesulitan keuangan, kesulitan keluarga, persepsi stres, tekanan hukum memiliki hubungan yang signifikan terhadap munculnya ide bunuh diri, selain itu beberapa kondisi kronis seperti penggunaan minuman beralkohol secara berlebihan dan berbagai bentuk kesulitan yang dialami (keputusasaan, depresi, kecemasan dan rasa sakit) juga menjadi faktor pemicu ide bunuh diri. Menurut Chochinov, Wilson, Enns dan Lander (1998) ide bunuh diri juga dapat ditimbulkan oleh ketidakberdayaan individu.

Menurut Reynolds (1991) dalam Journal of Personality Assessment yang membahas mengenai pengukuran ide bunuh diri, menyatakan bahwa ide bunuh diri dapat dibedakan menjadi dua yaitu:

a. Keinginan dan rencana bunuh diri yang spesifik

Pemikiran umum terkait kematian dan keinginan untuk mati mulai dari yang ringan hingga rencana spesifik yang serius serta cara mengakhiri hidupnya atau bunuh diri.

b. Ide bunuh diri terkait reaksi dari orang lain

Pemikiran khusus yang lebih luas dibandingkan dengan keinginan dan rencana untuk bunuh diri spesifik. Pemikiran ini terkait dengan reaksi orang lain, termasuk persepsi orang lain terhadap harga diri seseorang setelah mengalami kematian. Selain itu bunuh diri dianggap sebagai bentuk balasan adalah kognisi yang terjadi pada domain ini.

Terdapat sebuah teori mengenai langkah-langkah sebelum terjadinya bunuh diri yaitu The Three-Step Theory (3ST) of Suicide menurut Klonsky \& May (2015). Dalam teori ini menjelaskan mengenai tahapan menuju timbulnya ide bunuh diri kemudian berlanjut pada ide yang kuat hingga dorongan yang memungkinkan terjadinya upaya bunuh diri. Langkah-langkah bunuh diri dalam 3ST yaitu (1) pengembangan ide bunuh diri, (2) ide yang kuat versus ide moderat dan (3) kemajuan dari ide menuju upaya yang dijelaskan sebagai berikut:

a. Pengembangan ide bunuh diri

Langkah pertama menuju ide bunuh diri dimulai dari rasa sakit terlepas dari sumbernya, baik itu rasa sakit psikologis maupun rasa sakit secara fisik. Ketika individu memiliki pengalaman hidup dengan rasa sakit dan memiliki harapan yang rendah terdahap masa depannya maka hal ini menjadi dorongan yang kuat terhadap berkembangnya ide bunuh diri.

b. Ide yang kuat versus ide moderat

Keterhubungan individu dengan kehidupan sosialnya seperti hubungan dengan orang terdekat, pekerjaan, peran dan minat memiliki pengaruh dalam perkembangan ide 
bunuh diri. Ketika keterhubungan lebih kuat dibandingkan dengan rasa sakit dan keputusasaan maka individu cenderung hanya memiliki ide pasif dan tidak berkembang menjadi keinginan aktif. Apabila rasa sakit dan keputusasaan lebih kuat dibandingkan keterhubungan maka individu cenderung memiliki ide bunuh diri yang kuat dan keinginan aktif untuk mengakhiri hidupnya. Selain penekanan pada rasa sakit, keputusasaan, dan keterhubungan, faktor lain seperti depresi, keadaan pikiran, kepribadian, dan tempramen juga berhubungan dan berpengaruh terhadap pekembangan ide bunuh diri.

c. Perkembangan ide menuju upaya bunuh diri

Secara biologis dan evolusi, manusia dapat menghindari cedera, rasa sakit dan kematian hal ini dikarenakan oleh naluri manusia terhadap ketakutan akan kematian. Oleh karena itu sulit bagi individu untuk memutuskan melakukan upaya bunuh diri, namun dalam teori ini dijelaskan bahwa terdapat tiga kategori variabel yang dapat meningkatkan kapasitas ide bunuh diri menjadi upaya bunuh diri yaitu dispositional, acquired, dan practical. Dijelaskan bahwa dispositional mengacu pada genetika dan sensitivitas terhadap rasa nyeri sedangkan acquired mengacu pada pengalaman individu, seperti pengalaman rasa sakit, luka, kecemasan dan kematian. Kemudian variabel praktis mengacu pada pengetahuan dan akses yang memudahkan individu untuk melakukan upaya bunuh diri.

Berdasarkan tahapan dalam The Three-Step Theory (3ST) of Suicide dapat diketahui bahwa ide bunuh diri dapat berkembang menuju upaya dan tindakan bunuh diri.

\section{Kesimpulan}

Ide bunuh diri merupakan rencana awal dari upaya bunuh diri yang diakibatkan oleh berbagai faktor dalam kehidupan. Meskipun dikatakan bahwa sebagian individu yang memiliki ide tidak melakukan upaya bunuh diri, namun berdasarkan kajian literatur ini diketahui bahwa individu yang mengalami berbagai kombinasi peristiwa negatif dalam kehidupan cenderung berpotensi lebih tinggi melakukan upaya bunuh diri. Kombinasi yang dimaksudkan yaitu upaya bunuh diri tidak hanya didorong oleh satu faktor melainkan beberapa faktor pendorong, misalnya individu yang mengalami depresi, keputusasaan serta memiliki akses untuk bertindak tentunya berisiko lebih tinggi untuk mewujudkan ide bunuh diri menjadi upaya bunuh diri. Dalam melakukan pencegahan terhadap upaya bunuh diri maupun tindakan bunuh diri, penting untuk mengkaji lebih lanjut mengenai penyebab dan alur perkembangan bunuh diri. Oleh karena itu kajian ini diharapkan dapat membantu pembaca dalam memahami ide bunuh diri serta perkembangannya dalam mencegah upaya dan tindakan bunuh diri dimasa depan. 


\section{Referensi}

Aulia, N., Yulastri, \& Sasmita, H. (2019). Analisis Hubungan Faktor Risiko Bunuh Diri dengan Ide Bunuh Diri pada Remaja. Jurnal Keperawatan, 11(4), 307-314. http://journal.stikeskendal.ac.id/index.php/Keperawatan/article/view/534/385

Chochinov, H. M., Wilson, K. G., Enns, M., \& Lander, S. (1998). Depression, hopelessness, and suicidal ideation in the terminally ill. Psychosomatics, 39(4), 366-370. https://doi.org/10.1016/S0033-3182(98)71325-8

Dewan Pers. (2019). Draft Pedoman Pemberitaan Terkait Tindak dan Upaya Bunuh Diri.

Ibrahim, N., Amit, N., \& Suen, M. W. Y. (2014). Psychological factors as predictors of suicidal ideation among adolescents in Malaysia. PLoS ONE, 9(10). https://doi.org/10.1371/journal.pone.0110670

Klonsky, E. D., \& May, A. M. (2015). The Three-Step Theory (3ST): A New Theory of Suicide Rooted in the "Ideation-to-Action" Framework. In International Journal of Cognitive Therapy (Vol. 8, Issue 2).

Klonsky, E. D., May, A. M., \& Saffer, B. Y. (2016). Suicide, Suicide Attempts, and Suicidal Ideation. Annu. Rev. Clin. Psychol. 2016, 12, 307-337. https://doi.org/10.1146/annurev-clinpsy-021815-093204

Leenaars, A. A. (2010). Edwin S. Shneidman on Suicide. Suicidology Online, 1, 5-18. https://www.researchgate.net/publication/49583087_Edwin_S_Shneidman_on_S uicide

Liu, Y., Usman, M., Zhang, J., Raza, J., \& Gul, H. (2019). Making Sense of Chinese Employees' Suicide Ideation: Does Meaning in Life Matter? Omega (United States), 003022281984672. https://doi.org/10.1177/0030222819846721

Mackenzie, S., Wiegel, J. R., Mundt, M., Brown, D., Saewyc, E., Heiligenstein, E., Harahan, B., \& Fleming, M. (2011). Depression and Suicide Ideation Among Students Accessing Campus Health Care. American Journal of Orthopsychiatry, 81(1), 101-107. https://doi.org/10.1111/j.1939-0025.2010.01077.x

Nock, M. K., Borges, G., Bromet, E. J., Alonso, J., Angermeyer, M., Beautrais, A., Bruffaerts, R., Wai, T. C., De Girolamo, G., Gluzman, S., De Graaf, R., Gureje, O., Haro, J. M., Huang, Y., Karam, E., Kessler, R. C., Lepine, J. P., Levinson, D., Medina-Mora, M. E., ... Williams, D. (2008). Cross-national prevalence and risk factors for suicidal ideation, plans and attempts. British Journal of Psychiatry, 192(2), 98-105. https://doi.org/10.1192/bjp.bp.107.040113

Ranieri, W. F., Steer, R. A., Lavrence, T. I., Rissmiller, D. J., Piper, G. E., \& Beck, A. T. (1987). Relationships of depression, hopelessness, and dysfunctional attitudes to suicide ideation in psychiatric patients. Psychological Reports, 61(3), 967-975. https://doi.org/10.2466/pr0.1987.61.3.967 
Reynolds, W. M. (1991). Psychometric Characteristics of the Adult Suicidal Ideation Questionnaire in College Students. Journal of Personality Assessment, 56(2), 289-307. https://doi.org/10.1207/s15327752jpa5602_9

Sulistyorini, W., \& Sabarisman, M. (2017). DEPRESI : SUATU TINJAUAN PSIKOLOGIS. Sosio Informa, 3(2). https://doi.org/10.33007/inf.v3i2.939

Vilhjalmsson, R., Kristjansdottir, G., \& Sveinbjarnardottir, E. (1998). Factors associated with suicide ideation in adults. Social Psychiatry and Psychiatric Epidemiology, 33(3), 97-103. https://doi.org/10.1007/s001270050028

WHO. (2019). Suicide. https://www.who.int/news-room/fact-sheets/detail/suicide 